Revue bibliographique pour le domaine irano-aryen

\title{
Marco Moriggi. A Corpus of Syriac Incantation Bowls. Syriac Magical Texts from Late-Antique Mesopotamia
}

\section{Christelle Jullien}

\section{(2) OpenEdition}

1 Journals

\section{Édition électronique}

URL : http://journals.openedition.org/abstractairanica/44574

DOI : 10.4000/abstractairanica.44574

ISBN : 1961-960X

ISSN : 1961-960X

Éditeur :

CNRS (UMR 7528 Mondes iraniens et indiens), Éditions de l'IFRI

Référence électronique

Christelle Jullien, « Marco Moriggi. A Corpus of Syriac Incantation Bowls. Syriac Magical Texts from LateAntique Mesopotamia », Abstracta Iranica [En ligne], Volume 37-38-39 | 2018, document 22, mis en ligne le 30 décembre 2018, consulté le 27 septembre 2020. URL : http://journals.openedition.org/ abstractairanica/44574; DOI : https://doi.org/10.4000/abstractairanica.44574

Ce document a été généré automatiquement le 27 septembre 2020.

Tous droits réservés 
Marco Moriggi. A Corpus of Syriac Incantation Bowls. Syriac Magical Texts from Late-Antique Mesopotamia

Christelle Jullien 


\section{RÉFÉRENCE}

Marco Moriggi. A Corpus of Syriac Incantation Bowls. Syriac Magical Texts from Late-Antique Mesopotamia. Leiden: Brill, 2014, XVIII-278 p. (Magical and Religious Literature of Late Antiquity 3), ISBN 9789004272804.

L'A. offre là une étude très complète et à jour d'une série de 49 bols à inscriptions incantatoires rédigées en syriaque retrouvés en Babylonie et en Mésopotamie, datant vraisemblablement de la période sassanide. Ces matériaux avaient été publiés de manière éparse depuis 1853 et jusqu'en 2012; cette édition est donc à la fois une synthèse et un travail de philologie critique. Cette analyse est accompagnée de traductions nouvelles, de photographies et de facsimilés qui en font un outil très commode. Elle s'intéresse à la paléographie des écritures estranghela et manichéenne utilisées sur ces bols, et l'A. propose à cette occasion une étude graphique totalement renouvelée. Il convient de rappeler que ces bols à inscriptions ont été utilisés et fabriqués par diverses communautés religieuses de ces territoires, aussi bien zoroastriennes que juives, chrétiennes, mandéennes ou païennes, et ce en dépit des mises en garde des autorités hiérarchiques référentes contre des pratiques parallèles à caractère magique. Outre leur intérêt philologique, ces objets constituent de précieux indicateurs pour mieux comprendre les différents aspects des croyances de ces communautés, les realia de leurs pratiques religieuses au quotidien, et aussi l'évidence d'influences réciproques. Une bibliographie, des glossaires détaillés ainsi que des listes des divinités et entités angélologiques et démoniaques viennent compléter utilement ce fructueux volume.

\section{AUTEURS}

\section{CHRISTELLE JULLIEN}

CNRS, Mondes iranien et indien, Paris 